\title{
DESCRIPTION AND CHARACTERISTICS OF 81 PATIENTS ATTENDING THE REFERENCE CENTER FOR MULTIPLE SCLEROSIS OF THE COASTAL REGION OF THE STATE OF SÃO PAULO - BRAZIL
}

\author{
Yara Dadalti Fragoso', Ana Patricia Perez Fiore ${ }^{2}$
}

\begin{abstract}
Objective: to register multiple sderosis (MS) patients residing in the coastal region of the State of São Paulo (CEREM Litoral Paulista). Method: Individual interviews with identified cases of MS. Results: 81 individuals with diagnosis of MSagreed to come for registration (62 females [76.5\%], 19 males [23.5\%]). $65 \%$ of all patients were residents of the dity of Santos. The mean age of these patients was 43 years (14 to 74 years), and the Expanded Disability Status Scale (EDSS) was $\leq 5.5$ in $76.5 \%$ of the cases. $82.7 \%$ of the assessed patients presented the relapsing/renitting form of MS. $81.5 \%$ of all patients were underg oing treatment with immunomodulators. Conclusion: Due to their clinical profile, patients seem to come to CEREM Litoral Paulista for prescription of immunomodulators. There is a clear need to identify other cases in the region and to allow other forms of treatment to be put into practice.
\end{abstract}

KEY WORDS: multiple sclerosis, immunomodulators, city of Santos.

\begin{abstract}
Descrição e características dos 81 pacientes em seguimento no Centro de Referência em Esclerose Múltipla do litoral paulista.

RESUMO - Objetivo: Registrar os pacientes portadores de esclerose múltipla (EM) residentes na região do litoral paulista (CEREM Litoral Paulista). Método: Entrevistas individuais com casos identificados de EM. Resultados: 81 indivíduos com diagnóstico de EM (62 mulheres [76,5\%] e 19 homens [23,5\%]) concordaram em comparecer para registro no centro. $65 \%$ do grupo total de padientes eram residentes da cidade de Santos. A idade média destes pacientes era 43 anos (14 a 74 anos), e o Expanded Disability Status Scale (EDSS) foi $<5,5$ em $76,5 \%$ dos casos. $82,7 \%$ dos pacientes registrados apresentava a forma remitente-recorrente de EM. $81,5 \%$ de todos os pacientes estava recebendo tratamento com imunomoduladores. Conclusão: Pelo perfil clínico, os pacientes parecem vir ao CEREM Litoral Paulista para prescrição de imunomoduladores. Existe uma clara necessidade de identificar outros casos na região e permitir que outras formas de tratamento sejam implantadas.
\end{abstract}

PALAVRAS-CHAVE: esclerose múltipla, imunomoduladores, cidade de Santos.

Patients with suspected multiple sclerosis (MS) a reincreasingly being referred to specialized centers for diagnosis, treatment and follow-up ${ }^{1}$. The ch ronic and disabling characteristics of MS are dete minants of substantial costs ${ }^{2,3}$, since young aduIts are often obliged to restrict their economic and social activities, either temporarily or on a permanent basis. The direct and indirect costs of MS increase with the severity of the disease. The advent of immunomodulatory drugsthat may modify the course of the disease may also have created an extra burden on the budgets of governmental depar- tments dealing with public health ${ }^{4}$. The Consensus and Guidelines for prescription of these immunomodulators are strict and complex ${ }^{5,6}$, therefore creating the need for specialized centers to which patients need to be referred for prescriptions of such drugs.

Specialized centers for MS care have been created in Brazil in the last decade, and data regarding clinical characteristics of patients from some of these centers have been published ${ }^{7-14}$. With the recent creation of a Reference Center for MS care in the coastal region of the State of São Paulo, we

CEREM Litoral Paulista, DIR XIX, Department of Health for the State of São Paulo; Department of Neurol ogy, Medical Faculty of Universidade Metropolitana de Santos (UNIMES), Santos SP, Brazil: 1MD, MSc, PhD; Lecturer in Neurology, Medical School UNIMES; 2BSC, Head Nurse; Lecturer of Nursing School UNIMES 
now have descriptive data on our patients, which we present here. Our aim is to add to our data to that of other centers, in an attempt to characterize MS in Brazil.

Up to January 2002, all patients suspected of, or diagnosed with MS, who resided in the coastal region of the State of São Paulo, were being ref erred to distant terti arycenters for evaluation. Once they were evaluated at these specialized centers and immunomodulators were prescribed, the patients could continue their treatment in the city of their residence, receiving their medication from the city of Santos branch of the State Health Department Pharmacy.

In January 2002, by request from the State Health Department of São Paulo, a new center for MS was created in the city of Santos, attending a total population of 1,500,000 inhabitants of more than 20 towns in the region. This center was set up through an agreement between the State government and the Medical School of Universidade M etropolitana de Santos (UNIMES). In May 2003 our center was acknowledged as a "Reference Center" for MS, in an official publication from the State government. We then started the process of identifying and registering all cases of MS, observing their clinical characteristics, and determining patients' needs.

\section{METHOD}

By request from the State Health Department of São Paulo, all patients diganosed as MS were required to register in our Reference Center. Such registration was performed by means of a consultation with clinical evaluation of the patient (history taking, dinical and neurological assessment) and review of exams requested by the neurologists in charge of these patients.

We started the registration by calling all patients who were already receiving medication for MS, fro $m$ the Santos branch of the State Health Department Pharmacy. They were requested to come for a consultation at a set date and time. All neurologists and neuro su rgeons of the region were informed of our center, and encouraged to refer their patients for registration. The invitation to patients was made by telephone, and the reasons for this request were dearly stated to them and to their doctors. Any other MS patients who could be identified in the region were also requested to come fo $w$ ardfor registration. All interviews took place between August 2003 and April 2004. An association of patients with MS, created at the same time, encouraged patients to come forward for registration with us.

Upon collecting data from all cases that came for registration with us, we performed a retrospective evaluation of clinical records of these patients.

\section{RESULTS}

A total of 83 individuals were identified as MS patients ( 63 females, 20 males). Except for two cases, all patients readily agreed to come for the interview and registration at the center. Of the total group of 83 individuals, $65 \%$ of them were residents of the city of Santos (which accounts for less than $30 \%$ of the population of the region). It is in Santos that more than $90 \%$ of neurologists and neurosurgeons of the region live and practice. The further away from Santos that we looked, the fewer the numbers of diagnosed cases there were. A summaryof the distribution of the population and the diagnosis of MS in the coastal region of the State of São Paulo is shown in the Table. It is possible that, despite diagnosis, some patients from the region may not be registered with us, though all efforts were made to locate all diagnosed cases during this period of registration.

The 81 patients who registered with us consisted of 62 females (76.5\%) and 19 males (23.5\%). Two patients $(2.4 \%)$ were dark-skinned of African origin, two $(2.4 \%)$ were mulattos and one $(1.2 \%)$ was of oriental origin. All remaining patients were Caucasians (94\%). The mean age of these 81 patients was 43 years (range $=14$ to 74 years), and the Expanded Disabilitay Status Scale (EDSS) was $\leq 5$ in $76.5 \%$ of cases. $82.7 \%$ of all patients presented the relapsing/remitting form of MS (RRMS). On average, patients had had the diagnosis of MS for 9 years and the first symptoms appeared, on average, at the age of 32 years (range $=14$ to 61 ). The most frequent and disabling persistent symptom

Table. Number of inhabitants in the cities of the coastal region of São Paulo, according to the latest census, in comparison to the total number of diagnosed patients with MS in each of these cities.

\begin{tabular}{lccc}
\hline City & $\begin{array}{c}\text { Number of } \\
\text { inhabitants }\end{array}$ & $\begin{array}{c}\text { Number of } \\
\text { cases of MS }\end{array}$ & $\begin{array}{c}\text { "Prevalence" of } \\
\text { MS per 100,000 } \\
\text { inhabitants }\end{array}$ \\
\hline Santos & 417,000 & 52 & 12.5 \\
São Vicente & 303,000 & 10 & 3.3 \\
Guarujá & 265,000 & 4 & 1.5 \\
Praia Grande & 193,000 & 9 & 4.6 \\
Cubatão & 108,000 & 2 & 1.9 \\
Itanhaém & 72,000 & 2 & 2.8 \\
Registro & 54,000 & - & - \\
Mongaguá & 35,000 & 1 & 2.9 \\
Bertioga & 30,000 & 1 & 3.3 \\
Jacupiranga & 17,000 & - & - \\
Others & 206,000 & - & - \\
\hline
\end{tabular}

We observe a higher "prevalence" of diagnosed MS in larger cities and in particular, in Santos, where most neurologists live and work. 
was fatigue both for men (40\%) and for women (37.7\%). Currently, $84.3 \%$ of all 83 patients diganosed with MS in the coastal region of São Paulo are undergoing treatment with immunomodulators, though only 81 of them areregistered with us and their clinical data can be discussed. The remaining two patients who live in the area but did not come for registration with us continue their t reatment in tertiary specialized centers in the city of São Paulo.

The two patients who refused to come for registration had their immunomodulatory drugs prescribed in another Reference Center, and their compliance and satisfaction with the treatment could not be assessed. Out of the subgroup of 81 fully registered patients, we identified 68 individuals in use of immunomodulators $(83.9 \%$ of our registered population of 81 patients). Detailed assessment of this group is presented below.

Patients in use of immunomodulators - This sub$g$ roup of MS patients consisted of 53 women and 15 men. The average age was 41 (range $=14$ to 65 ). The total number of consultations with neurologists regarding initial symptoms that resulted in no diagnosis of MShad been 103 for women (1.9consultations per patient without diagnosis) and 19 for men (1.2 consultations per patient without diagnosis). A much larger number of consultations with other specialties that did not result in diagnosis of MS was identified, but the patients could not spedfy the total number of such consultations. At the time of the consultation that confirmed the diagnosis, all of them received a prescription for immunomodulators by their private neurologists.

The median EDSS score was 3.0 for this group of patients undergoing treatment (range =zero to 8). Although all patients in use of immunomodulators had MS diagnosed according to the criteria of Poser ${ }^{15}$, not all of them had clear indication for the use of immunomodulatory therapy. Regarding guidelines and recommendations for the use of immunomodulators ${ }^{5}$, we informed the doctors of the four patients who did not fulfill the criteria for such t reatment (two cases of EDSS $\geq 7$, and two cases of elderly patients who had not presented any relaps es of MSfor many years). In all four cases, the doctors agreed to suspen the prescription, using only symptomatic medication and rehabilitation.

Regarding their expectations from treatment with immunomodulators, only $18.9 \%$ of women and $33.3 \%$ of men expected simply a decrease in the frequency of bouts. A much higher percentage ( $47 \%$ of all 68 patients) expected the medications to completely suppress bouts, or to allow them to return to nomal life, to be free of symptoms and even to be cured. Possibly as a result of their expectations, only $10.3 \%$ of our patients declared they were totally satisfied with the treatment.

$37.7 \%$ of the women and $53.3 \%$ of men were not particularly dissatisfied with the fact that they had to be treated with frequent injections. However, $47.2 \%$ of women and $40 \%$ of men claimed the treatment was painful or troublesome, while the remainder of dissatisfied patients daimed that the injections were frightening or complicated to use. All patients were required to inject themselves in the presence of the nurse, and $54 \%$ of them did not perform the injections correctly. A similar number of patients admitted to "taking holidays" or "days off" occasionally, so that they could "have a rest" from the injections.

\section{DISCUSSION}

Registration of our patients showed that diagnosis of MS was clearly related to the number and availability of neurologists in the cities of the region, as well as the presence of health-related faculties. The city of Santos is the largest in the area, and it is in Santos that Universities are concentrated. There is a dear need to identify other cases in the region and, from early 2005, a special educational program is to take place in this area of the State.

The higher prevalence of the disease in women (ratio female: male $=3: 1$ ) is similar to that reported by other Brazilian authors ${ }^{7-14}$. The predominance of Caucasians affected by the disease in our group seems to be higher than that reported in other Reference Centers in Brazil7-14.

Patientsregistered in the center tended to be relatively young, with low EDSS, less than 10 years of MS, and predominance of RRMS. Rather than suggesting that our patients present a relatively benign form of MS, this seems to indicate that patients are coming to our center for prescription of immunomodulators. Only 13 patients who are not in use of such drugsare registered with us. Although the Ref erence Center offers free assessment and treatment for speech and swallowing disorders, physiotherapy, psychiatric evaluation, ophthalmologic assessment, relaxation exercises, etc, few patients make use of such facilities. Those who regularly come to the patients' meetings and are registered 
with us prefer to continue exclusively for the prescription of the injections of immunomodulators. Patients from private dinics and other hospitals are equally interested in medication, giving little attention to rehabilitation. A special educational program is now starting in order to make this point clear: treatment of MS is not exclusively done by means of injections of immunomodulators.

Possibly due to unrealistic expectations of immunomodulatory treatment, $89.7 \%$ of patients undergoing such therapy were not particularly satisfied with the results. Although these patients may have fewer or no new relapses of the disease with such treatment, they may still be dissatisfied because they had expected much more. Simply by using the injections (and often using them inadequately), $53 \%$ of the patients expected cure or complete supression of relapses.

Results from our Reference Center, specially organized to attend patients residing in the coastal region of the State of São Paulo have brought to light a variety of problems among MS patients. Rather than being exclusively descriptive, registra tion of patients has pointed out the difficulties we face in the region and has lead to the implementation of educational programs for patients and health professionals.

\section{REFERENCES}

1. Wingerchuck DM, Carter JL. Practical consultations: multiple sclerosis. Semin Neurol 2003;23:253-264.

2. Prosser LA, Kuntz KM, Bar-Or A, Weinstein MC. Cost-effectiveness of interferon beta-1a, interferon beta 1-b, and glatiramer acetate in newly diagnosed non-primary progressive multiple sclerosis. Value Health 2004;7:554-568.

3. Philips CJ. The cost of multiple sclerosis and the cost effectiveness of disease-modifying agents in its treatment. CNS Drugs 2004;18:561-574.

4. Flachenecker P, Rieckmann P. Health outcomes in multiple sclerosis. Curr Opin Neurol 2004;17:257-261.

5. Lana-Peixoto MA, Callegaro D, Moreira MA, et al. The BCTRIMS Expanded Consensus on treatment of multiple sclerosis: III. Evidence and recommendation-based guidelines. Arq Neuropsiquiatr 2002;60:881-886.

6. Treatment optimization in multiple sclerosis: report of an international consensus meeting. Eur J Neurol 2004;11:43-47.

7. Leite ACCB, Andrade C, Novis S. Esclerose múltipla no Rio de Janeiro: a presentação clínica em 51 casos. Arq Neuropsiquiatr 1990;48(Supl):66A.

8. Lana-Peixoto MA, Lana-Peixoto MIV. Is multiple sclerosis in Brazil and Asia alike? Arq Neuropsiquiatr 1992;50:119-125.

9. Papais-Alvarenga RM, Santos CMM, A b reu JS et al. Esclerose múltipla: perfil clínico e evolutivo no munícipio do Rio de Janeiro. Rev Bas Neurol 1995;31:75-87.

10. Tilbery CP, Felipe E, Baldauf CM, Peres MFP. Esclerose múltipla: análse clínica e evolutiva de 214 casos. Arq Neuropsiquiatr 1995;53:203-207.

11. Oliveira EML, Annes M, Oliveira ASB, et al. Esclerose múltipla: estudo clínico de 50 pacientes acompanhados no Ambulatório de Neurologia UNIFESP-EPM. Arq. Neuropsiquiatr 1999;57:51-55.

12. Moreira MA, Felipe E, Mendes MF et al. Esclerose múltipla: estudo descritivo de suas formas clínicas em 302 casos. Arq NeuroPsiquiatr 2000;58:460-466.

13. Arruda WO, Scola RH, Teive HAG, et al. Multiple sclerosis: report on 200 cases from Curitiba, Southern Brazil and comparison with other Brazilian series. Arq. Neuropsiquiatr 2001;59:165-170.

14. Fer reira MLB, Machado MIM, Vilela ML, et al. Epidemiologia de 118 casos de esclerose múltipla com seguimento de 15 anos no centro de referência do Hospital da Restauração de Pernambuco. A rq Neuropsiquiatr 2004;62:1027-1032.

15. Poser CM, Paty DW, Scheinber L et al. New diagnostic criteria for multiple sclerosis: guidelines for research protocols. Ann Neuro 1983;13:227-231 